\title{
Discussing Civilisation and Informalisation: Criteriology
}

\author{
Cas WOUTERS \\ Utrecht University, Países Bajos \\ c.wouters@uu.nl \\ Stephen MENNELL \\ University College of Dublin, Irlanda \\ Stephen.mennell@ucd.ie
}

Recibido: 10-09-2012

Aceptado: 19-12-2012

\begin{abstract}
Norbert Elias's theory of civilising processes has been received only marginally in the USA, one of the obstacles being the absence of figurational or process studies of American society. In the first decade of this century this situation was changed by the publication of Stephen Mennell's The American Civilizing Process (2007) and Cas Wouters' Sex and Manners (2004) and Informalization (2007). By 2012, Randall Collins had reviewed the first and the third books in two essays (2009, 2011).

His claims and criticism of civilising and informalisation theory are discussed in this paper by placing them in the context of the reception history of Elias's work since the 1960s, when a first round of discussion centred on criteria to be used for determining the direction of civilising processes. A second round was in the 1990s, and in this paper we contribute to a new round by presenting a summary of earlier critical discussions in an attempt to establish a more solid and subtler body of criteria for studying civilising processes. We use this in critically discussing Collins's contributions, linking them to symbolic interactionism, American National Ideology, and blind spots in American sociology.
\end{abstract}

Key words: civilising processes; informalisation; Norbert Elias; Randall Collins; American National Ideology; American sociology

\section{Referencia normalizada}

Wouters, C., Mennell, S. (2013). Discussing Civilisation and Informalisation: Criteriology. Política y Sociedad, Vol.50 Núm. 2: 553-579

Sumario: Introduction. 1.The first round of discussion. 2.The second round of discussion. 3.The third round of discussion. 4.Symbolic interactionism and the concepts of 'habitus' and 'trend'. 5.Conclusion. References 


\section{Introduction}

Elias's theory of civilising processes has been received only marginally in the USA. A major obstacle for Americans to open a discussion on the Elias perspective has been the absence of figurational or process studies of American society. In the first decade of this century this situation was changed by the publication of books by the present authors: Stephen Mennell's The American Civilizing Process (2007) and Cas Wouters's Sex and Manners (2004) and Informalization (2007). The American Civilizing Process is modelled on Elias's magnum opus, On the Process of Civilisation (2012a [1939]), attempting to give a broad view of both habitus formation and state formation processes in America over the whole sweep of history since the first European settlements. Sex and Manners and Informalization deal extensively with changing manners in the USA since 1890, comparing them with these changes in three European countries.

Wouters's studies were received favourably, among others by Peter Stearns (2007) who in his book American Cool (1994) had critically discussed both the theory of civilising processes and informalisation theory. In his later book Battleground of Desire: The Struggle for Self-Control in Modern America (1999) he came to embrace the interpretation of an informalisation process, for example in sentences such as 'In sum, manners became more informal while demands for systematic emotional control became more stringent' and 'Americans were told to become less stiff but more cautious' (1999: 154). However, his adoption of an informalising process was left without consequence for either informalisation theory or the theory of civilising processes.

In 2009, sociologist Randall Collins was the first American to discuss Stephen Mennell's book. He published a long and rather flippant review, thus prompting what in this paper we perceive as a third round of theoretical discussion. Collins's critique, however, was directed primarily at Norbert Elias's theory of civilising processes; he has only praise for Mennell's discussion of the 'macro-structural development of the US', this part he even calls 'a triumph' (p. 433). But he attributes this triumph to Mennell's position as a foreigner and outsider, not to Elias's theory. Collins's critique of the theory of civilising processes spills over from Elias's original On the Process of Civilisation to Mennell's book and also to Wouters's Informalization.

Collins views Elias's theory as the 'historicisation of Freud, a social history of the growth of the superego', to which his main objection is that it represents a 'deep weakness': that it is a 'trend theory', with a single track that 'goes from spontaneous instinctual expression, to external social control, to the internalisation of controls as self-restraint' (2009: 431). The title of his review - 'The end of a trend theory' - therefore proclaims the end of the theory of civilising processes. This sounds promising, for it raises the expectation of a serious theoretical discussion.

However, Collins provides no quotations and thus leaves all of his claims unsubstantiated. This goes for his reproach that 'the civilising process' is essentially 
good, leading inevitably and in a straight line to morally better and mentally happier people - in his words, to 'wonderful things' such as the 'omni-pacification of the world', 'world government ... benevolent socialism and universal love' (p. 432). It also goes for his claim that in Informalization, Wouters makes 'a heroic effort' to bring the counter-culture examples of informalisation 'under the Elias paradigm with the argument that this is just a further stage of egalitarianism, and thus a continuation of the civilising process to a higher level of internalised concern for other people' (p. 437). These are all empty claims. To be sure, we feel tempted to argue that civilising processes surely did change direction in the last decades of the nineteenth century when the formalisation of manners lost its dominance to an informalisation of manners, but that this process of informalisation and its inherent emancipation of emotions did not bring an end to the disciplining of people. Quite the reverse: rising levels of self-regulation were demanded to live up to the relaxation of codes and cope with the increased and differentiated options. In this respect, therefore, civilising processes had continued in the same direction. But specifying this argument would be boxing the air because Collins positioned his evaluations in the air, above any onus of proof.

Moreover, Collins is unaware of several decades of sociological discussions about these questions, which can be divided into three 'rounds'.

\section{The first round of discussion}

Confusing the direction of civilising processes and its evaluation is a major problem. This error was made in the 1970s by Dutch sociologists who, like Collins today, also understood Elias's theory as a single-track or unilinear theory of increasing affect-control. From this perception it follows that the level of civilisation rises if self-control rises, as a result of which asking for the direction of the civilising process is almost automatically turned into asking for its evaluation.

An example can be taken from the work of Brinkgreve and Korzec, who simplified Elias's theory as 'the theory of increasing self-control' (1976: 29). These Dutch sociologists conducted research into social changes between the 1950s and the 1970s, and in an early report they concluded that an interpretation in terms of Elias's theory was impossible for want of a clear criterion. As such, they explained, the concept of self-control is too ambiguous, for it may connote repression as well as mastery of emotions. In the eyes of Brinkgreve and Korzec, this ambiguity made the theory irrefutable because self-control appeared as repressive or oppressive (bad) on the one hand, and as mastery (good) on the other. They omitted to study their data for the possibility that growing leniency in the codes of conduct implied a

${ }^{1}$ For a more detailed discussion of the 'first round' of debate in the 1970s and 1980s, mainly among Dutch sociologists and anthropologists, see Mennell (1998 [1989]: 227-50). 
change from having to control towards being able to control and/or express emotions, a change towards the 'emancipation of emotions' as it was conceptualised by Wouters.

Dutch sociologist Nico Wilterdink did the same (1973). That Elias does not interpret the relaxation of codes after the First World War "as a "reversal" of the civilising process, because it occurred in the context of a far-reaching degree of affect-control' met with his judgement 'that way, every manifest change towards diminishing control can be tucked away'.

Collins appears to be in good Dutch company, although it is company of at least 35 years ago. Therefore, those familiar with the two rounds of discussion on Elias's work in the Netherlands, much of his critique reads like returning to old polemical issues. The first round of discussions was in the 1960s and 1970s, when everywhere in 'the West' taboo after taboo was broken, and when the increase of 'permissiveness' was welcomed with relief by some and experienced by others as a forerunner of a breakdown of civilisation.

This last interpretation was to be discussed more extensively in the second round of discussion, in the early 1990s. Interest in the direction of civilising processes flourished again because of shifts in global balances of power, especially the tensions and conflicts surrounding the collapse of the USSR and Yugoslavia (Mennell, 1994). The interconnected outbreaks of violence and various insecurities in international relations in particular had triggered new interest in the direction of civilising processes. The new key concepts were disintegration of states and decivilising processes.

The first round of discussion started in the 1960s when increasing numbers of students, among others, read the new German edition of Über den Prozess der Zivilisation. In Amsterdam, particularly among sociologists and historians, the discussion centred on the questions whether the civilising process had changed direction and what the observed changes meant for the theory of civilising processes. In 2009, Collins has raised the same questions regarding changes in the USA. Already in his first paragraph, his stance is unambiguous: 'from the point of view of the Norbert Elias theory, the US would seem to be leader of the decivilising process'.

This stance is debatable, but let us first present some 'old' criticism of Collins's description of the 'deepest weakness': 'The civilising process starts with spontaneous impulses, essentially Freud's Id, which are gradually brought under social control and then internal control' (p. 440). The formulation suggests a beginning and a sequence that are both non-existent. There is no zero or starting point in civilising processes (as Elias endlessly stressed), if only because children are universally raised according to the codes of parents, their representatives and the survival group they are born and raised in.

That sequence is an 'old' misunderstanding, too. It is as if self-controls take over from social controls and the latter diminish or erode where self-control emerges. This is not the case. Indeed, in the long-term phase of formalisation covered by Elias in his major book, what he calls the 'social constraint towards self-constraint' 
tends predominantly towards conscience formation - to the transformation of direct fear of others into an inner fear transmitted via conscience into a more or less automatically functioning 'second nature'. This implied a change in the exercise of social controls: whereas before they were directed at preventing people from becoming involved in forbidden situations and relations, thus blocking possibilities of yielding to temptation, they became increasingly exercised on the self-regulation of people who are now expected to prevent transgressions under their own steam. External social controls changed direction, but did not diminish. On the contrary: the social sanctioning of behaviour showing a flawed control of conscience gained ascendancy.

In the first round of discussion, Wouters drew attention to the process of informalisation in an article (in Dutch) entitled 'Has the civilising process changed direction?'(1976). In processes of social competition and interweaving, people have come to pressure each other to more reflexive and flexible manners and thus also to a type of self-regulation attuned to these manners. More often, and time and again, they were faced with the task of surmounting their fears with regard to social and psychic authorities. In this process, various emotions and impulses entered consciousness and public discussion. With this 'emancipation of emotions' much self-evident repression changed in the direction of obvious temptation. All in all, the pressure of social controls on individuals mounted and again changed direction: the locus and focus of social controls increasingly came to rest with a sprightly conscious self-regulation (Ego), if only because of the need to live up to mounting demands of flexible, sensitive and deliberate manners and manoeuvring.

In this 1976 article Wouters pointed out that Elias never used just 'increase' or 'decrease' of self-restraints as a criterion, but was always more differentiated: 'Individuals are compelled to regulate their conduct in an increasingly differentiated, more even and more stable manner (Elias, 2012: 406). He also referred to more allround and more automatic self-restraints. 'More all-round' refers to a trend towards social standards of self-restraint applying more uniformly to all situations and relations: social demands for extreme self-control in specific situations becoming increasingly less compatible with an equally extreme readiness to act in accordance with one's impulses in other situations. 'More even' refers to a diminution of extremes, by becoming less volatile and more even-tempered or steady in all types of relations. 'More automatic' refers to the spread of a second-nature type of habitual self-restraints.

Furthermore, Wouters discredited the efficacy of using just one criterion: 'All kinds of interconnected criteria are included in the theory of civilising processes' (p. 340). In part four of Elias's book, entitled 'Overview: Towards a theory of civilising processes', next to the balance of controls - the balance between external and internal social controls - various other criteria apply. One is the balance of power (or, better, 'power ratio'): 'Increasing constraints on the upper class: increasing pressure from below.' A lessening of power inequalities induces the spread of informal manners and emancipation of emotions. Brinkgreve and Korzec ignored this connection by placing it outside the theory. After having concluded that 
Elias's theory cannot be confirmed or contradicted, they turned to look for 'other explanations', and pointed to the lessening of inequalities (and to the growth of wealth), thus reducing the civilising theory once again to its self-restraint component (1976: 30).

Last but not least was the point that it makes little or no sense to discuss isolated examples and to try to assess whether they prop up the theory or not. A recent example is Collins's discussion of obscene speech and his interpretation of efforts at prohibition as 'a reversion to external constraint' (2009: 437). Well, yes, there are many more similar examples in other fields, where external controls were expanded and intensified because increasing numbers of people started to calculate the risk of not buying a ticket on public transport, or of cheating to pay less tax or to receive more social welfare benefits. Thus, the level of trust in the self-controls of clients and citizens declined, and authorities organised more and firmer social controls. But the theoretical point is that it makes little or no sense to discuss one isolated example, for the theoretical relevance of a range of systematically obtained examples only stands out in the context of changes in the whole balance of controls, and in related balances such as power ratios. What counts are changes in the whole pattern of controls and their relation to other yardsticks or criteria of civilising processes.

\section{The second round of discussion}

Nico Wilterdink reduced the theory of civilising processes to its self-restraint component in the first round, and he kept doing it in the second round of discussion of the 1990s. In a special issue of Amsterdams Sociologisch Tijdschrift on the theory, he wrote that the direction of civilising processes according to Elias can be determined from the question whether self-control has become more or less allround, even and differentiated, and that these criteria are insufficient (1995). In a reaction entitled 'Criteriology' (1997), Wouters concluded that it was apparent that the result of the first round of discussion was that the single criterion for determining the direction of civilising processes had been somewhat differentiated, but that the fallacy of self-control being the criterion had remained.

This thought, Wouters argued in 'Criteriology', albeit typical of the Amsterdam discussion, is not to be found in Elias's work. Subsequently, he pleaded again in favour of other theoretical criteria such as the scope of identification between individuals and groups, psychologisation and rationalisation, diminishing contrast and increasing varieties, and all the other criteria mentioned as headings in Part Four of On the Process of Civilisation.

In his response to 'Criteriology', Wilterdink (1997) presents two arguments against 'bringing in' more criteria. The first reason is that more criteria block the possibility of making a distinction between describing civilising processes and explaining them: 'If, for example, state formation is part of a civilising process, it is impossible to argue simultaneously that state formation is at the basis of the 
civilising process. The explanation of civilising and decivilising processes can never be found if everything is included in these processes.' Wilterdink apparently thinks that the direction of these processes can be determined by something outside them. In our view there is nothing against seeing and studying the entire history of humankind from the perspective of the theory of civilising processes. It would mean searching for the interconnections included in the theory, such as interconnections between social and psychic structures and processes. Apparently Wilterdink confuses 'process' and 'theory'.

Incidentally, we do not believe Elias ever claimed that state formation was the basis or 'cause' of the civilising process. He shuns such a causal formulations because a cause of social and psychic processes is as rare as a beginning. In his sociological theory of knowledge and the sciences, with which Wilterdink is certainly familiar (see Wilterdink, 1977), but to which Collins makes no reference, Elias (2007, 2009a) makes clear that while simple billiard-ball causal models are appropriate in the physical-chemical sciences, the biological sciences already require four-dimensional models of developmental processes through time, while the social sciences involve five-dimensional models, in which human experience forms the fifth dimension in addition to space and time. A hint of this can be seen in the summary statement that he makes at the end of the (original) first volume of On the Process of Civilisation:

if in this or that region the power of a central authority grows, if over a larger or smaller area the people are forced to live in peace with each other, the moulding of affects and the standards of the drive-economy are very gradually changed as well. (2012a: 196)

But note that, although the internal pacification of everyday life within a territory by means of the gradual monopolisation by the forces of the state of the legitimate right to employ the means of violence - state formation processes are not the single prime mover of habitus formation processes. Rather, a whole series of partprocesses are intertwined with each other in a spiral process. Internal pacification promotes trade over longer distances, which promotes the division of labour and economic growth and the growth of towns, which yield increased taxes, supporting more effective administration, bigger armies and bigger wars to acquire more territory, which leads to still more extensive internal pacification, and so on. Thus, many processes for which social scientists have separate words - state formation, division of labour, economic growth, urbanisation, bureaucratisation, and so on are not in empirical fact separate from each other. And it is the overall process which, according to the theory of civilising processes, exerts a steady external constraint towards self-constraint. 
Earlier figurations develop into later figurations; they are not the beginning or the cause of later figurations. Nor can later figurations explain earlier ones. ${ }^{2}$ Developments largely proceed as a 'blind process' - that is, rather independent of the intentions of the people involved - and they often go hand in hand with counterprocesses, which implies that the course of developments could have been different. The process-sociological task is to demonstrate empirically how earlier figurations have developed into later ones, keeping an eye open for counter-developments or 'counter-histories' (Goudsblom, 1995: 262).

Thus, a process of state formation is certainly to be included as part of a civilising process, but not as part of the theory of civilising processes, because in some groups the confinement and control of violence as a means of settling conflicts is achieved differently. Anyway, state formation is not among the titles of sections in Elias's 'Overview: towards a theory of civilising processes', but the 'courtisation' or 'taming of the warriors' - in short, pacification - is included.

The second reason why Wilterdink is against 'bringing in' more criteria is that it enlarges arbitrariness. The various criteria bring contradicting results, he argues, and contradictions necessarily lead to arbitrary interpretations because an unambiguous decisive answer is unattainable. This may hold some water, but only from a static point of view. The existence of processes and counter-processes makes nonsense of attempts at reaching out for unambiguous decisive answers. In any period, civilising and decivilising trends can be discerned, although usually at different levels of integration as, for example, in violence within states and violence between states. The same goes for integrating and disintegrating trends, if only because processes of integration imply 'integration conflicts' (see Mennell, 2007: 214-48).

Take for example the social integration of many societies in the 1960s and 1970s when economy was expanding, wealth was rising and a general material security spread (in many countries also via the arrangements of a welfare state). This social integration at the level of states went hand in hand with rising relational insecurity and decreasing interdependence on the level of families. Many families disintegrated and there was a sharp increase of divorce.

The search for an unambiguous assessment of civilising or decivilising traits from an arbitrary variety of examples therefore seems sterile. Confronted with passing and partial processes and counter-processes at several levels of integration, the process question is which of the two, civilising and decivilising trends, is dominant (see Dunning and Mennell, 1998).

Another reason for rejecting law-like mechanistic causal relations between changes in self-control and changes in power ratios - as effected, for example, in state formation processes - is that changes in the balance of power and in the

2 See Elias (2012b), chapter 6, "The problem of the "inevitability" of social development'. 
balance of controls cannot be studied separately because they are heavily entangled: exercising social control is exercising a form of power. Therefore, the study of changes in ways of exercising social controls cannot avoid all ambiguity, because these controls open a window on power and dependency relations while being an integral part of these relations. ${ }^{3}$

In his response, however, Wilterdink insists on the necessity of being unambiguous. Without it, he writes, the question of whether the highly organised and disciplined violence of the Nazi destruction camps can count as 'decivilising', cannot be answered, except arbitrarily. But this arbitrariness only exists owing to the arbitrary isolation of this moment in time from a larger framework and a longer process.

Four years later, Abram de Swaan (2001) raised the same point about the destruction camps of Nazi Germany, where decivilised activities took place in 'reserves of destruction', while the rest of society remained pacified as before. De Swaan describes how these secluded places allowed for a psychic, social and geographical process of compartmentalisation to take place. By the inclusion of compartments of destruction and barbarity, the course of the civilising process was 'bent'. This bending he calls a process of dyscivilisation.

Compartmentalisation as a defence mechanism is incompatible with a process of informalisation or with a transition 'from management of relations through command to management through negotiation', as De Swaan termed it (1990), because dyscivilising societies tend to foster strong, but also quite rigid types of social control and self-control.

Very elaborate codes of conduct and expression will be maintained to the smallest detail, until the moment that one steps over the threshold and into the compartment of barbarity, where all cruelty and wildness are permitted, until one leaves this reservation again and resumes one's controlled demeanour, as if nothing had ever happened: that is dyscivilised behaviour. (De Swaan, 2001; italics in original; see also Elias, 2013)

This behaviour touches upon two of the criteria mentioned by Elias, the evenness and all-roundness of constraints, for the existence of a compartment of cruelty and fury implies that the civilised restraints are neither altogether all-round nor even. De Swaan's description can be compared with Elias's description of

the self-control demanded in some Amerindian societies of their young men during initiation rites where they were tortured but expected not to show by any

${ }^{3}$ It is a sad irony that Elias drew attention to social and self-controls in the 1930s, connecting emotions to changing balances of power, and yet so many social scientists today break the connection he made between the regulation of emotions and power ratios. It is equally ironic that most of those who describe themselves as working in the 'sociology of emotions' have little or no interest in connections between emotions and power (and the minority who do have such an interest hardly ever use Elias's theory). 
movement or sound that they suffer pain. That was a preparation for their warrior existence. They should not shame their tribe if they were taken prisoner by another tribe and tortured by losing their pride and showing that they suffered. ... the social demand for self-restraint is confined to a highly specific situation and perfectly compatible with an equally extreme readiness to act in accordance with one's libidinal and affective impulses in other situations. (Elias letter to Cas Wouters, 13 October 1976, quoted in Wouters 2007: 232; see also Elias, 2007: 126-31)

Using De Swaan's and Elias's words, Nazi Germany was a society in which strong but rather rigid types of social control and self-control prevailing in most situations was perfectly compatible with an equally extreme readiness to act out all conceivable cruelty and fury in a highly specific and confined situation. The comparison shows the importance of a standard of controls with criteria for 'greater evenness and all-roundness in all, not only in some situations' and 'removed from extremes' (Elias in Wouters, 2007: 232-3). It also shows that the same goes for social controls.

One of the conclusions of Wouters's study of changes in the codes of manners and emotion regulation over more than a century is that 'both major wars and their aftermath seem to have had little independent lasting effect on the overall trend' and 'that the barbarity of the wars was of small significance for overall developments in regimes of manners and emotions' (2007: 173). To do justice to the horrors of periods full of violence such as these two World Wars is only possible, of course, by zooming in on the atrocities. Inquiry into the significance of these periods within long-term processes, however, demands a higher level of detachment, which may arise from zooming in and out, by studying events alternately from a smaller and a greater distance. Thus their place can be seen from short-term as well as from a long-term perspective, which includes a view on the moment when time stood still in horror as well as on the partial and passing moment of decivilisation. As long as the first view dominates and the second one hurts, mourning and/or shame prevail. In that case, the long-term perspective may lose so much validity and meaning that it meets with moral indignation.

\section{The third round of discussion}

Not World Wars, but culture wars and informalisation, are in the centre of the third round of discussion, which was triggered by the American sociologists Collins and Davetian. Both misunderstand informalisation. Collins's main attempt is to show there is no such thing as informalisation - that it is in fact decivilisation - and Davetian's critique of Elias's theory of civilising processes fans out in many directions (see reviews by Goudsblom, 2011, and Wouters, 2010). 


\subsection{Davetian's Civility}

In his book Civility: A Cultural History (2009), the Canadian-American Davetian overlooks both Mennell's 2007 book and also Wouters's book Informalization. He distorts the process and theory of both informalisation and civilisation. From his interpretation that 'the bolder members' of the 1960s cultural movement reformed 'the long process of evolution of manners', it can already be deduced that Davetian's view of the 'Expressive Revolution' is rather one-dimensional. He says that it probably was not a decivilising process: 'That certain segments of culture dared become less inhibited - and consequently more spontaneous - may not have been an indication of a decivilising process but of how secure (or bored) Americans had come to feel with their rational approach to reality' (p. 305). Davetian proceeds: 'Cass [sic] Wouters (1986: 1-18) suggests that this deformalisation [sic!] and 'decontrolling' was made possible by the efficiency of previously imposed restraints. His view accords with that of Elias ([1939] 1978), who ... considered the reversal a "relaxation within the framework of an already established standard", (2009: 140).

After having reduced informalisation theory to what Elias had written already in the 1930s on bathing customs in the 1920s and 1930s, he comes up with an alternative interpretation:

But what both Elias and Wouters may be ignoring is that ... a decivilising process did not occur not only because the notion of civilised behaviour was sufficiently anchored in the human psyche, but because many continued to remain inhibited and in control while the spontaneous went on their freedom trip. While a certain number tuned in and dropped out, the majority continued doing their work, fixing the plumbing, carrying the garbage to the dumps, putting out fires, and so on.

This trifling idea borders on the grotesque, because it is accompanied by naïve oneupmanship: 'So to look back and say that some of the wild and unrestrained behaviour was due to hyper-efficient previous restraints is to reveal a need to preserve theoretical consistency at all costs' and 'may be based on an unwillingness to part with historical continuity' (p. 306).

When arguing that 'humans are not capable of managing without a certain degree of stability and custom', Davetian once more makes a perfunctory and selective use of one of Wouters's articles on informalisation. He writes (p. 332): 'Even informality can become formalised into a form of its own (Wouters, 1986)', thus using an aspect of the informalisation process merely to dress up this platitude.

In his discussion of the 1960s, Davetian argues: 'What Elias has considered a long process of evolution of manners was cheerfully reformed within a few months by the bolder members of the 1960s cultural movement. The restraint of bodily functions, described by Elias as a sine qua non of the civilising process, was substantially abridged' (p. 305). Apparently Davetian is unaware that the theory of informalisation implies that the Western civilising process consists of a long-term process of formalisation, dominant from the sixteenth up to the last quarter of the 
nineteenth century, after which a process of informalisation has prevailed. Randall Collins does not make this distinction either, but for a different reason.

\subsection{Collins's culture war}

The Collins review contains the old misapprehensions that the theory of civilising processes is restricted to the development of self-controls, and that Elias offers an explanatory model for 'the single-track trend' of a waxing conscience. He thinks Elias has presented three 'important causes': (1) 'the elimination contest among states', (2) 'state monopolisation of force' - the 'prime mover in the whole process' (p. 433) - and (3) 'increasing interdependence among persons, locales and institutions leads to an increasing feeling of constraint and reliance on others, hence to "functional democratisation" - greater sensitivity to the needs of others, and hence to greater democracy and equality' (pp. 431-2). This quotation shows how Collins, too, confuses the process and the theory of civilisation. And his formulation suggests that these 'causes' mentioned in the explanatory model are placed outside the process of civilisation. If so, what about the place of 'increasing feeling of constraint and reliance on others' and 'greater democracy and equality'? Aren't those actually part of - well, of what, in fact? Does Collins perceive the explanatory model as part of civilising theory or of civilising process? Or are both to be incorporated into what he alternatively terms 'the Elias paradigm'? It remains vague.

Collins criticises 'the Elias paradigm' most firmly and strongly by attacking 'the Wouters paradigm' - process and theory of informalisation - and by twisting it: there is no informalisation, the 'culture war' he sees going straightforwardly amounts to 'decivilisation'. In sum, the single-trend track has changed direction, at any rate in the USA! For Americans chew gum, speak slang, drink coke from the can, eat tacos, burritos, pizza slices and other snacks with their fingers all day while almost having altogether abandoned 'the very old ritual of enacting group solidarity by commensality' (p. 435). In his very first paragraph Collins claims that Americans have been 'breaking the tired old crust of European "civilisation"' and now boast "We're uncivilised and proud of it!"” (p. 431). In passing he also mentions that 'many trends, especially in popular youth culture, in sports, violence or crime, raise the challenge of whether there is a decivilising process' (p. 432), but without pursuing the matter. His main substantiation consists of examples of his proposition that standards of cleanliness and order are not observed, that they are even deliberately violated: 'it is a culture of rebellion'. He mentions women wearing torn cloths and men having 'a perpetual grizzled look, a "five-o'clock" shadow' - which must demand a certain amount of careful planning always to be in the intermediate stage of hairiness (p. 436). Subsequently he writes: 'This is not merely a shift to casual clothes formerly associated with the working class, such as blue jeans and T-shirts - which is plausibly interpreted as egalitarian and democratic informalisation - but deliberate transgression for its own sake' (p. 436). 
With these words he again attaches a positive value judgment - egalitarian and democratic - to the concept of informalisation, while simultaneously restricting its meaning to this judgment. In this context it seems relevant that Collins uses the word 'deliberate' twice, without explicating why intentionality is theoretically relevant. Therefore, the word can only function as a run-up to his conclusion: 'No, this is an aggressive counter-culture coming from the middle class' (p. 436). ${ }^{4}$ On this basis he also concludes that this trend is not informalisation but decivilising thus providing it with a negative value judgment and reducing its meaning to this judgment.

However, evaluating changes in manners and self-regulation as good or as bad is irrelevant to deciding whether and how these changes contribute to the process of informalisation or contradict the trend, or whether they contribute to a decivilising process. And we would argue that all the examples Collins presents can be brought under the heading of informalisation of manners, and that none of them is unique to the USA.

Since the 1890s, but particularly since the 1960s, displays of conspicuous respectability have been increasingly experienced as inappropriate displays of superiority, inciting moral indignation. Indeed, many examples of informalisation are deliberately rebellious and provocative transgressions for their own sake, which quite often means not demonstrating conspicuous respectability. The 'culture wars' of the 1960s and 1970s indeed consisted of deliberate provocations against the establishment and their highbrow culture, and they were also, as Collins rightly observes, carried by a 'counter-culture coming from the middle class'. Their protests contributed to a relaxation of rigid and unambiguous codes of manners without diminishing demands on self-regulation. Quite the contrary, on the whole the relaxation was placing greater demands on self-regulation such as an increasingly reflexive and flexible regulation, capable of fine-tuning. In our eyes, Collins's examples of wearing torn cloths, a stubbly beard, drinking from the can and eating with fingers, seem far too innocent to lump together under the heavy concept 'culture war'. And his evaluation is far too negative. Why not attach weight to the fact that provocations have contributed to a dramatic decline of social and individual censorship?

Provoking the established order has also become politically and economically rewarding. In many countries, populist political parties have come to thrive on this sentiment. And the economic viability of provocative clothing brands like 'PORN STAR' (US), 'FCUK' (UK) and 'CCCP' (Netherlands) indicate that many people

${ }^{4}$ It needs to be borne in mind that when Americans speak of 'the middle class', they mean what the rest of the world calls the 'working class', a term they avoid because of its Marxist connotations that are incompatible with American National Ideology. In American usage, 'middle class' includes everyone in any kind of steady employment; only the 'underclass' are below it. 
have come to take provocative pleasure in wearing T-shirts and caps with PORN STAR on them, shirts and sweaters with a great FCUK or, in addition to a small emblem with the hammer and sickle symbol, a huge CCCP on them. A daring competition in provocation has indeed been one of the driving forces of the informalisation process.

Take the famous declaration of counter-culture in Bob Dylan's song Ballad of a Thin Man (1965). It harbours an idealisation of 'street sense' and straightforward contempt for the established - and their 'real-life hang-up'. The song's protagonist Mr Jones functions as prototype of an established intellectual who does not know what happens in real life:

You've been with the professors, and they've all liked your looks. With great lawyers you've discussed lepers and crooks. You've been through all of F. Scott Fitzgerald's books. You're well read, it's well known. But something is happening here and you don't know what it is. Do you, Mr Jones?

The derision in these words (and in the music) typifies the provocative superiority display of counter-culture. Collins claims that 'the aggressive counter-culture is a move towards asserting one's superiority'. Indeed. What he does not mention is that superior jeers countered the aggression and superiority display of the established, that Dylan here scoffs at the usual and often unwitting contempt of Mr Jones for the lower classes and the lower emotions and impulses, against which a counter-culture raised counter-aggression and counter-superiority.

This 'culture war' was part of a status competition between classes and states that still continues in and between most or all Western countries. Collins thinks that Americans have 'elaborated a set of status-groups, independent of class', but we think this view is pure American ideology (see Mennell, 2007: 250-1). This status competition is far from being 'independent of class', nor is it typically American. The social movement of people trying to demonstrate superiority in street sense above salon sense (the subtle intimation that one is not a person of the street) spread from the 1960s onwards and became loudly expressed in all western countries. Today, it is still alive and kicking, if only in the many spiteful expressions coming from populist leaders. Large parts of the population, including among the middle classes, have become almost explosively sensitive to old Mr Jones's displays of superiority. In this process, status competition and its inherent feelings of superiority and inferiority have become increasingly covered and hidden.

In the eyes of Collins, 'the trends in popular manners have been precisely those which are not covered by expositors of etiquette' and therefore, 'etiquette books have probably become increasingly weak indicators of actual manners, especially in the later twentieth century' (p. 434). Certainly, manners books contain dominant manners, not all manners, but Collins goes too far and brings Mr Jones to life again by continuing that 'of course such writers still exist and have some kind of market, but they look increasingly like emulators of the old-fashioned upper class fighting a rearguard action, and losing' (p. 434). 
The view that dominant trends do not appear in manners books belongs to an old tradition. It is a characteristic expression of people and groups who are socially rising, aspire to a lifestyle and expression of their social value by being accepted into good society, and as yet are excluded from entering. But Collins really seems to think that the tradition of writing manners books has been eroded to the point where these publications only represent the lifestyle of a minority of the elegant and sophisticated, the happy few of yesteryear who are on the point of being overruled. This view strongly overrates the importance of the 'aggressive counter-culture coming from the middle class'.

The same happens again where Collins writes that the counter-culture is responsible for creating a split between 'a healthy minority of upper-middle class sophisticates' and 'a very strong mass culture of anti-sophisticates' (p. 435). Thus he suggests that the healthy minority is a losing group. Such a strong formulation is indicative of an equally strong cultural pessimism. The strong image of the 1960s revolt having become a strong mass movement of 'anti-sophisticates' is reminiscent of The Revolt of the Masses (1930), Ortega y Gasset's monument of cultural pessimism.

And yet we retain some doubts: does Collins really think that 'good manners' and the whole genre of 'manners books' are waning and on the brink of being washed away by 'aggressive counter-culture coming from the middle class'? For the time being our best bet is that he made an heroic effort to build up his counterculture examples of informalisation to a position against the theories of civilisation and informalisation.

\subsection{Collins's theories of informalisation}

In 2011, Collins continued his discussion of informalisation. Now, he admits that informalisation processes have continued for over a century. He questions, however, 'whether we have the theoretical explanation right'. He says he 'will summarise alternative theories', but what he proposes is merely 'various kinds of informalisation' by presenting a taxonomic differentiation in four categories. He distinguishes many of them as elites that established themselves since the 1950s with new styles of self-presentation: the cool-casual-sexy elite; the leisureathletic-fantasy elite; and the sheer antinomian ugliness-shock elite. Collins calls them theories because he thinks their explanations differ. One of them, ascribed to Wouters, is the kind of informalisation 'caused' by democratisation. 'Informalisation is the levelling of class lines', he writes. This is a reduction and a simplification.

Wouters has, indeed, written that diminishing power differences incite informalisation because a decline in social distance prompts people towards greater informality, but he has not written that all informalisation 'is' or 'expresses' democratisation. Obviously, both trends, the decline of power differences and the informalisation of manners, have been dominant from the 1890s until the 1980s at 
least, but since the mid-1960s their interconnectedness has become less direct and therefore less clear. From then on, direct expressions of class difference, status triumphs and other displays of superiority (and inferiority, for that matter) became increasingly tabooed and counter-productive, so to speak. Most direct expressions were chased away from the public scene. To some extent they went underground into deeper layers of the personality, or they went underground by expressing them only in private, or in sports, or in reverse, or dressed up in disguise.

During the 1960s, superiority in reverse was expressed in the romanticisation of people such as psychiatric patients, 'working-class heroes', hoboes, beatniks, and other non-conformists living in relatively unprotected and dangerous social conditions. In his essay Funky Chic, Tom Wolfe presented the example of clothing fashions of the early 1960s, when

well-to-do whites began to discover the raw-vital reverse-spin funk thrill of jeans and other 'prole gear', whereas the 'hard-core street youth in the slums ... were into the James Brown look ... so that somehow the sons of the slums have become the Brummels and Gentlemen of Leisure, the true fashion plates of the 1970s, and the Suns of Eli dress like the working class of 1934 (Wolfe, 1976: 182-9).

This idealisation of street sense was one side of a coin that had a straightforward or hidden contempt for the established (and their real-life hang-up) as its other side. As has been said earlier, on this side is the provocative counter-superiority display of Bob Dylan. In his songs, Dylan not only ridiculed the established, but also parts of his audience, thus practising a form of Publikums-beschimpfung, an art form introduced in 1966 by Peter Handke. Another way of provoking authority, and probably also of dealing with the rising taboo on feelings of superiority, is the use of irony. Irving Berlin did this in his 1946 lyric 'Anything you can do, I can do better. I can do anything better than you'. Later, in 1980, the American Mac Davis was successful in sending up status triumphs by exaggerating them in his song 'It's hard to be humble (when you're perfect in every way)'.

Collins presents interesting examples, most of them variations of hidden expressions of superiority, reversed or dressed-up in disguise. We agree that these are 'various kinds of informalisation' (his words), but Collins emphasises differences in motivation, some elitist, some egalitarian, some just to draw attention, and then takes it for granted that different motivations need different explanations. We tend to see mixtures and blends of motivations, all rooted in the same quite complicated status competition in rather egalitarian societies in which the more direct and extreme expressions of superiority (and inferiority) have become tabooed, chased away, and therefore went underground or found reverse or disguised expression. The various manifestations and motivations apparently have much in common; they stem from very similar developments in status competition and the presentation of self.

Actually, Collins mentions a fourth variety (and theory) of informalisation: fashion cycles coming around and going around. He mentions 'skirt lengths (including mini-skirts)' as one example, but his 'cycle' view leaves the whole 
process of sexualisation in the dark: skirts lengths have gone up, women and men dress more sexily, behave more sexily, and have become more strongly aware of sexuality, and so on (see Wouters, 2004). When writing about disguised expressions of superiority, Collins contradicts his 'cycle' view by writing: 'techniques of presenting oneself as sexy in public situations have escalated for a century'. And: 'The sexiness elite made its appearance already in the 1920s, with shorter skirts for women' (2011: 166). In our view, all this is part of a sexualisation process, and 'informalisation refers to a process that entails sexualisation' (Wouters, 2011a). The sexy self-presentation is not related to class or ethnicity, Collins writes, for 'the key analytical point is that sexual attractiveness is stratifying in an autonomous dimension .... a distinctive kind of social performance and presentation of self'. Because this presentation has an elitist motivation, 'this is not mere informalisation; and it is not democratisation, but an effort to establish a new kind of visible eliteness during the time when informalisation was also occurring' (2011: 166).

Indeed, Collins distinguishes his four kinds of informalisation to a large extent on the motives and intentions of individual people. However, in their status competition and related trials of strength, it is much more common for people to be driven by other motives than egalitarian ones, motives such as looking good and winning. As a rule, the motive of being equal is seen only in people who suffer from and fight inequality and injustice, and only when they think of having a good chance of success. When more egalitarian presentations of self became a fashion, the motives did not stem from egalitarian motives alone: another necessary condition was a collective identification with rising outsiders, bringing the electrifying expectation of success, of looking good and winning. Only in phases of collective emancipation, such as the 1920s and 1960s, do the changing balances of power coincide with social controls and sanctions favouring egalitarian presentations and disfavouring non-egalitarian ones. In subsequent phases of accommodation, when collective emancipation chances have disappeared and individuals who want to rise socially have become more dependent upon groups and individuals in socially superior positions, collective identification has tended to shift in the direction of the established, but no longer as unquestioningly nor as collectively as in the phase of collective emancipation. Moreover, the more extreme expressions of superiority and inferiority remained tabooed and a more widely differentiated spectrum of options in self-presentation remained socially accepted, implying a 'reformalisation' without changing the direction of the longer-term overall process of informalisation.

Collins's reduction of what Wouters means by informalisation implies that any informalisation that is not 'caused' by democratisation should need a different explanation, a different theory. This we find a strange conception of theory: it is less than a 'theory of the middle range', and more a mini-theory of a micro range. The scope of the other three 'theories' Collins proposes - his non-egalitarian kinds of informalisation - is even smaller, and the question how they are related is not raised, turning them into four isolated mini-theories. He writes that he believes the 'causes' of non-egalitarian informalisation over the last 50 years are to be found in 
'the micro-structure of everyday interaction'. It seems likely that this strong focus on individual motives is another symptom of the American celebration of individual self-determination. It is also a symptom of Collins's fundamentally symbolic interactionist assumptions - of which more later.

Collins claims that making use of the forename normative, and increasingly shifting to nicknames, is an American-originated pattern. In discussing this change he writes 'First-naming is not just democratisation but pseudo-intimacy' and that

shifting to nicknames, implies something further. It most resembles a youth style, in which everyone has the status of children who never take on adult roles. The American pattern is to treat all situations as much as possible as leisure ones. (2011: 164)

This interpretation in terms of an American youth style is interesting, but it seems more probable, we think, to locate its origins in the aristocracy. An orientation to leisure, self-confidence and ease clearly derive from the aristocratic tradition. Lord Chesterfield referred to 'ease' as 'the last stage of perfection of politeness'. And, in twenty-first-century aristocratic circles, the use of nicknames is still common:

I have always been uncomfortable with the jejune pseudo-informality implicit in the upper-class passion for nicknames. Everyone is 'Toffee' or 'Bobo' or 'Snook'. They themselves think the names imply a kind of playfulness, an eternal childhood, fragrant with memories of Nanny and pyjamas warming by the nursery fire, but they are really a simple reaffirmation of insularity, a reminder of shared history that excludes more recent arrivals, yet another way of publicly displaying their intimacy with other. Certainly the nicknames form an effective fence. A newcomer is often in the position of knowing someone too well to continue to call them Lady So-and-So but not nearly well enough to call them 'Sausage', while to use their actual Christian name is a sure sign within their circle that one doesn't really know them at all. And so the new arrival is forced back from the normal development of friendly intimacy that is customary among acquaintances in other classes. (Fellowes, 2005: 57)

To treat all situations as leisure ones is also quite aristocratic, but in this respect too Collins prefers to classify by intention. 'Athletic clothes (including warm-up suits, running shoes, sweatshirts) worn on all occasions' are 'egalitarian informalisation', but the style of 'the athletic-leisure-fantasy elite' is 'informalisation but not democratisation - the preferred style was to look like, not the working classes, nor the ubiquitous middle-class business suit, but the older upper classes in their leisure moments in the country or at sports' (2011: 166).

In the rich West, these old upper classes and the lifestyles of their good societies seem to have retained much of their model-setting function; they are present in lifestyles and self-presentations such as being informal, polite, intimate, casual, at ease, confident, sexy, and always pottering about in a leisurely way. Today, many individuals and groups who form their niche in the spectrum of lifestyles characterised by these words, easily recognise each other in a feeling of familiarity. They are similar to people in today's aristocratic circles, of whom an intimate observer wrote that, 'when there is no one near to criticise them for it, they revel in 
this familiarity of the extended family. At their best, alone together and in a 'safe house', they are polite and unafraid, a charming combination' (Fellowes, 2005: 205). Outside the rich West, most expatriates and tourists tend to flock together for similar reasons. This analogy directs our curiosity to a comparison and a couple of questions. Ought we to compare class relations from before the 1960s on a national level with international (state) relations of today, wondering to what extent the lifestyles and the habituses of the old upper classes are being transformed in the shift to higher levels of global integration? And to what extent would they be continued if China rises further to global power? At what point would western upper-class lifestyles and habituses begin to intermingle and blend with those of the Chinese upper classes? And what would this mean?

\section{Symbolic interactionism and the concepts of 'habitus' and 'trend'}

Two more general questions arise from Collins's 2009 and 2011 essays. They centre on the concepts of 'habitus' and 'trend'. Collins, implicitly or explicitly, does not greatly care for these concepts, which also appear problematic from a symbolic interactionist perspective. Both Collins and symbolic interactionism are born and raised in the USA. The concepts 'habitus' and 'trend' appear to represent distinctly 'un-American' habits of thought.

\subsection{Habitus}

In his essays Collins does not employ the word of 'habitus', but his argument makes clear that he is implicitly rejecting it. The concept is central to Elias's work (as well as, obviously, to Pierre Bourdieu's). Collins ignores Wouters's discussion of the sociogenesis of American habitus (Wouters, 2007, 2011b), but his rejection of the very concept of habitus (or equivalent terms such as Riesman's 'social character') can be seen clearly in his remarks about Mennell's discussion of violence in American society: ${ }^{5}$

My own research, in Violence: A Micro-Sociological Theory (2008), shows that humans' main emotion in violent situations is not spontaneous aggression, but on the contrary tension and fear; special social conditions are necessary for people to become successfully violent, and in no situation are more than a minority of persons violent activists. This means that violence is socially constructed, right down to its micro-mechanisms. We cannot assume that all that is needed is for the state monopoly of violence to be taken off, and everyone will return to the Hobbesian state of natural belligerence. Thus when the state monopoly of violence disappears in the

\footnotetext{
${ }^{5}$ We should like to thank Helmut Kuzmics, University of Graz, Austria, for drawing our attention to this point.
} 
urban ghetto, gangs do not revert to medieval torturing of enemies. Instead they have constructed their distinctive forms of violence such as drive-by shootings. We need a much more proximal theory of the determinants of violence. (Collins, 2009: 440)

Substantively, in the face of Mennell's summary (2007: 122-57) of the massive evidence generated by American sociologists and criminologists of regional differences and long-term continuities in the incidence of violence in the USA, Collins is here exaggerating the general relevance of instances of fuite en avance or 'forward panic', an interesting syndrome that features prominently in his own micro-sociological treatment of violence. More important here, however, is the theoretical implication of what he says. It is a further symptom of his underlying commitment to symbolic interactionism, a characteristically American approach to sociology that (from an Eliasian viewpoint) has both strengths and weaknesses.

The strengths of symbolic interactionism, set out in founding essays by Herbert Blumer, are that it is processual and avoids what Elias (1978: 113-17) called 'process reduction' - the reduction of processes to a Meccano set of static conceptual parts (on the model of Parsons). Indeed, like Elias (who practised what Gleichmann, 1979, called 'concept avoidance), Blumer (1969: 153-70) advocated a 'science without concepts' and again like Elias (1978: 116), was sceptical of sociologists' use of the idea, derived from the natural sciences, of 'variables' (Blumer, 1969: 127-39).

The weaknesses of symbolic interactionism are well known: it remains firmly stuck at the level of face-to-face interaction, failing to deal with the ubiquitous social reality of interdependence. ${ }^{6}$ One is interdependent with infinitely more other people than those with whom one interacts face-to-face. Interdependence always involves more or less unequal balances of power. Where, as is usual, one person or group of people is more dependent on another person or group than the other party is on the first, there is an unequal 'power ratio'. Power ratios change over time, whether over a lifetime - as in the case of parents and their children - or over the longer term through historical struggles. In consequence, and crucially, neither inequalities of power nor history and long-term development play any part in symbolic interactionism. This implies the exclusion of the concept of habitus and long-term processes of self-regulation and habitus formation. How this exclusion is justified can be seen in remarks by Blumer on 'the nature of human action'. He argues against the

view of human action that dominates current psychological and social science. .... Action is traced back to such matters as motives, attitudes, need-dispositions, unconscious complexes, stimuli configurations, status demands, role requirements,

6 It thus fails even to attempt a solution to the so-called 'macro-micro problem' in sociological theory, to which in our view Elias's is by far the most sophisticated solution offered to date. Collins's own most ambitious attempt, in Interaction Ritual Chains (2004) remains essentially at the interactional level. 
and situational demands. To link the action to one or more of such initiating agents is regarded as fulfilling the scientific task. Yet, such an approach ignores and makes no place for the process of self-interaction through which the individual handles his world and constructs his action. The door is closed for the vital process of interpretation in which the individual notes and assesses what is presented to him and through which he maps out lines of overt behaviour prior to their execution. (1969: 15-16)

This quotation makes perfectly clear that any notion of 'habitus' beyond reflexive interpretation has to be avoided. Blumer makes this even more explicit when he rejects Watsonian behaviourism as much as psychoanalysis and Gestalt psychology (1969: 30).

And this is exactly the position that Collins adopts. Starting from such a position, and explicitly rejecting any idea of persistent social differences between groups of people arising from long-term processes of habitus formation, Collins cannot cross the bridge from his own micro-interactionist account of violence to the findings of his fellow sociologists about the macro-level distribution of American violence. Still less does he deal with how power struggles and long-term changes in power ratios are connected to long-term habitus formation. That connection is central to Elias's work, not only in On the Process of Civilisation, but also to such later work as Studies on the Germans (2013 [1996]), which is subtitled 'Power struggles and the development of habitus in the nineteenth and twentieth centuries'. Collins's distinction of four kinds of informalisation, four different motives and intentions is a symptom of his fundamental symbolic interactionism; and this emphasis on the importance of motives and intentions for scrutinising processes of self-interaction is both characteristic of symbolic interactionism and of the American National Ideology in which individual self-determination ranks high.

\subsection{Trend}

The insulting title of Collins's 2007 review essay, 'A dead end for a trend theory', may be taken as dismissive just of Elias's theory of civilising processes and the research tradition stemming from it. But its tone seems to imply a more general scepticism towards there being any identifiable long-term trends in social development of any kind. Such scepticism is widespread among sociologists, especially among those who lean towards interactionist micro-level research. In Britain especially, the influence of the philosopher of science Sir Karl Popper was widespread among social scientists in the post-war decades. In two famous books (1945, 1957), Popper drew attention to the dangers of 'historical prophecy', arguing that totalitarian rulers of both the extreme right and extreme left had sent millions to their deaths in the name of 'inexorable laws of historical destiny'. Popper's influence in the USA was probably much less direct, but had its equivalent in the teaching of scholars such as Robert Nisbet $(1967,1970)$, which chimed with the ideological hysteria of the Cold War years and with American National Ideology 
more generally. The result was that, for decades, sociology has been dominated by what Goudsblom (1977: 7) called 'hodiecentrism', or what Elias (2009b [1987]: 107-26) termed 'the retreat of sociologists into the present', in which history is treated as something separate, as 'background' - rather than as an integral part of any social process and sociological explanation. Elias argued that sociologists had to investigate 'the structure of processes' (see Bogner, 1986), and he tackled specifically the false 'problem of the "inevitability" of historical development' (Elias, 2012b: 153-70).

Elias was concerned to understand, retrospectively, how long-term processes could arise which, though overall they were unplanned, nevertheless had a more or less consistent direction over time. Elias described them as:

From plans arising, yet unplanned

By purpose moved, yet purposeless. (2011: 62)

Of course, there are some developmental trends with which sociologists have no difficulty in accepting as both being unplanned and persisting in the long-term. The most obvious is the division of labour, which is inevitably associated also with the growing web of human interdependence. Sociologists and economists have no difficulty either with the possibility that although the main trend of the division of labour has been continuing for millennia, it can in principle go into reverse, and sometimes - locally, and in general for shorter periods - has done so. In the main, the objection is not to blind, unplanned processes of a material - economic and technological - character, but rather to any suggestion that such trends can also be observed in the area of culture, self-regulation and habitus (see Liston and Mennell, 2009). This is an old pattern of thought, associated with, among others, Elias's teacher Alfred Weber (1935; 1998 [1921]), who admitted that a direction of development could be found in matters social and technological, but not in what he termed 'culture-movements'. So, where Elias offends most against the conventional wisdom is in linking long-term, unplanned, economic and social development - the division of labour, monetarisation, state formation and the rest - to an equally longterm and equally unplanned process in self-regulation and habitus, which he conceptualised as a civilising process.

The question of whether a sequence of social development can ever be said to be 'inevitable' has tended to become entangled with the philosophers' metaphysical antithesis of 'determinism' and individual 'free will'. The muddle is then further compounded when 'free will' is linked to 'freedom' in the sense of political and social liberty, and 'determinism' to lack of liberty. This link is false; as Elias points out, 'it is usually forgotten that there are always simultaneously many mutually dependent individuals, whose interdependence to a greater or lesser extent limits each one's scope for action' (2012b: 162). That simple sentence pithily cuts across centuries of metaphysical debate.

In On the Process of Civilisation, through his subtle handling of historical evidence, Elias demonstrates the inadequacy of the static polarity between 'inevitability' and 'indeterminancy' as it applies to social processes. In his later 
work, he often returns to the problem in more 'theoretical' terms. Models of developmental processes, or 'process-theories' are not theories conforming to the 'covering law' model of explanation, the model derived from classical physics advanced as an ideal by philosophers like Popper and the logical positivists, which has induced many sociologists into the neurosis called 'physics envy' (Mazlish, 1998).

Elias always stressed that processes of civilisation fluctuated, sometimes went into reverse and always contained counter-currents, but that there was abundant empirical evidence of changes in habitus proceeding in a specific direction over the long term. He did not say that the trend would inevitably continue in the same direction in the future. He did express the hope that future historians might come to look back upon the present era as that of the 'late barbarians' (Elias, 2011: 174), but his late writings are pervaded by the fear that humankind will destroy itself. We have a 50:50 chance, he used to argue, thus stressing the reversibility of social and cultural processes.

\section{Conclusion}

We began by noting the scant attention paid among American social scientists to the work of Norbert Elias. With a few exceptions - a notable instance being Steven Pinker's (2012) study of the long-term decline in interpersonal violence - they have continued to ignore Elias, even though over the last four decades he has come to be recognised across much of the rest of the world as one of the most important and sophisticated sociological thinkers of the twentieth century. Such commentaries on, or uses of, Elias as have emanated from the United States have tended to be oversimplistic. And not just that: they have tended to be based on a reading only of Elias's 1939 magnum opus, taking no account of his own elaborations of his ideas in a mass of books and articles from the 1970s and 1980s, let alone of the thriving 'figurational' research tradition.

Much of our article has been devoted to explaining four decades of research and academic research, in response particularly to Collins's and Davetian's critiques of Mennell, Wouters and Elias - and attempting to understand the weaknesses of reception of process sociology in the USA.

It begins to seem that there is something in American political culture, as well as in academic traditions that reflect it, that poses a major obstacle to an adequate understanding of Elias and of 'figurational' or 'process' sociology. From this perspective, a striking similarity between Davetian, Collins, and also Stearns, appears significant.

Stearns embraced the interpretation of an informalisation process but continued to reject both informalisation and civilising theory; Davetian seems to accept and reject parts of both theories but in a cavalier treatment; and while Collins embraced the 'macro-structural development of the US' as presented by Mennell, he contradicts his endorsement with an extensive negative critique of both theories, 
written offhandedly without a single reference. This similarity between these three American theorists, particularly Collins's refusal to go along with academic traditions by not providing references, can be understood as stemming from a lazy assumption that is characteristic of those who assume their position to be inviolable.

Collins's views are in so many ways quintessentially American. Mennell (2007: 312; 2011) has likened the relationship between the United States and the rest of the world to a one-way mirror in a social psychological observation laboratory. This seems characteristic of centres of power - global power, in this case - and of highly unequal established-outsider relations (Elias, 2004) between the established in the centre and those outside. Billions of educated people outside the USA know an immense amount about America, its constitution, its politics, its manners and culture; all these are extremely visible to the rest of the world. But America's huge power advantage seems to function something like a black hole: a mass of survey evidence suggests that Americans do not see out at all clearly, and tend to think about the 'outside world' if at all in stereotypical and indeed Manichean terms. This principle operates as much in the academic world as in the wider political and social realm. The Americans' power surplus remains firmly connected to collective superiority feelings on the one hand, and on the other is anchored to an American National Ideology of individualism and self-determination and to a focus on ideas and 'values'; and their gaze is turned away from interdependence - that is, from questions of power and unequal dependence - and from habitus.

Judging from a lazy assumption in the work of these three social scientists when writing about theories of civilisation and informalisation, feelings of superiority function as a major obstacle to a wider reception of process sociology. Perhaps its chances will advance with the rise of China and others as global powers, obliging Americans to remove more and more of the one-way screen behind which they live, and thus making them more inclined to realise more fully the significance or power relations and interdependencies, theoretically as well as practically. 


\section{References}

Blumer, Herbert (1969) Symbolic Interactionism: Perspective and Method. Englewood Cliffs, NJ: Prentice-Hall.

Bogner, Artur (1986) 'The structure of social processes: a commentary on the sociology of Norbert Elias', Theory, Culture and Society 20 (3): 387-411.

Brinkgreve, Christien en Michel Korzec (1976) 'Margriet weet raad. Gevoel, gedrag en moraal 1954-1974' Amsterdams Sociologisch Tijdschrift 3 (1): 17-32.

Collins, Randall (2004) Interaction Ritual Chains. Princeton, NJ: Princeton University Press.

Collins, Randall (2008) Violence: A Micro-Sociological Theory. Princeton, NJ: Princeton University Press.

Collins, Randall (2009) 'A dead end for a trend theory'. Archives européennes de sociologie, 50 (3): 431-41.

Collins, Randall (2011) 'Four theories of informalization and how to test them' in: Christien Brinkgreve, Marcel van den Haak, Bart van Heerikhuizen, Johan Heilbron, Giselinde Kuipers (eds.) Cultuur en ongelijkheid. Diemen: AMB, pp. 160-172.

Davetian, Benet (2009) Civility: A Cultural History. Toronto: University of Toronto Press.

Dunning, Eric and Stephen Mennell (1998) 'On the Balance between 'Civilizing' and 'Decivilizing' Trends in the Social Development of Western Europe: Elias on Germany, Nazism and the Holocaust'. British Journal of Sociology 49 (3): 339-57.

Elias, Norbert (1978) What is Sociology? London: Hutchinson.

Elias, Norbert (2013) Studies on the Germans: Power Struggles and the Development of Habitus in the Nineteenth and Twentieth Centuries. Dublin: UCD Press [Collected Works, vol. 11].

Elias, Norbert (2007) Involvement and Detachment. Dublin: UCD Press, 2007.

Elias, Norbert and John L. Scotson (2008) The Established and the Outsiders. Dublin: UCD Press (Collected Works, vol. 4).

Elias, Norbert (2009a) Essays I: On the Sociology of Knowledge and the Sciences. Dublin: UCD Press [Collected Works, vol. 14].

Elias, Norbert (2009b) Essays III: On Sociology and the Humanities. Dublin: UCD Press [Collected Works, vol. 16].

Elias, Norbert (2010) The Society of Individuals. Dublin: UCD Press [Collected Works, vol. 10].

Elias, Norbert (2011) The Symbol Theory. Dublin: UCD Press [Collected Works, vol. 13].

Elias, Norbert (2012a [1939]) On the Process of Civilisation: Sociogenetic and Psychogenetic Investigations. Dublin: UCD Press [Collected Works. Vol. 3].

Elias, Norbert (2012b [1970]) What is Sociology? Dublin: UCD Press [Collected Works, vol. 5].

Fellowes, Julian (2005) Snobs. London: Phoenix. 
Goudsblom, Johan (1977) 'Responses to Norbert Elias’s work in England, Germany, the Netherlands and France', in Peter Gleichman, Johan Goudsblom, Hermann Korte (eds) Human Figurations: Essays for Norbert Elias. Amsterdam: Amsterdams Sociologisch Tijdschrift.

Goudsblom, J. (1987) De sociologie van Norbert Elias. Amsterdam: Meulenhoff.

Goudsblom, J. (1995) 'De civilisatietheorie: kritiek en perspectief'. Amsterdams Sociologisch Tijdschrift 22 (2): 262-82.

Goudsblom J. (2010) Review of Civility: A Cultural History by Benet Davetian, in American Journal of Sociology 116 (3): 1043-45.

Liston, Katie and Stephen Mennell (2009) 'Ill Met in Ghana: Jack Goody and Norbert Elias on process and progress in Africa', Theory, Culture and Society 26 (7-8): 52-70.

Mazlish, Bruce (1998) The Uncertain Sciences. Princeton, NJ: Princeton University Press.

Mennell, Stephen (1994) 'The Formation of We-Images: A Process Theory', in Craig Calhoun, ed., Social Theory and the Politics of Identity. Oxford: Blackwell, pp. 175-97.

Mennell, Stephen (1998 [1989]) Norbert Elias: An Introduction. Dublin: UCD Press. [First edn published 1989 under title Norbert Elias: Civilization and the Human Self-Image.]

Mennell, Stephen (2007) The American Civilizing Process. Cambridge: Polity.

Mennell, Stephen (2011) 'America through the one-way mirror', International Journal of Contemporary Sociology, 48 (2): 217-48.

Popper, Karl R. (1945) The Open Society and its Enemies. 2 vols, London: Routledge \& Kegan Paul.

Nisbet, Robert A. (1967) The Sociological Tradition. New York: Basic Books.

Nisbet, Robert A. (1970) 'Developmentalism: a critical analysis', in J. C. McKinney and E. A. Tiryakian, eds, Theoretical Sociology: Perspectives and Developments. New York: Appleton-Century-Crofts, pp. 167-204.

Pinker, Steven (2011) The Better Angels of Our Nature: The Decline of Violence in History and its Causes. London: Allen Lane.

Popper, Karl R. (1957) The Poverty of Historicism. London: Routledge \& Kegan Paul.

Stearns, Peter N. (1994) American Cool: Constructing a Twentieth-Century Emotional Style. Albany, NY: New York University Press.

Stearns, Peter N. (1999) Battleground of Desire: The Struggle for Self-control in Modern America. Albany, NY: New York University Press.

Stearns, Peter N. (2007) 'Informalization and contemporary manners: The Wouters studies', Theory and Society 36: 373-79.

Swaan, Abram de (1990) The Management of Normality: Critical Essays in Health and Welfare. London: Routledge.

Swaan, Abram de (2001) 'Dyscivilization, Mass Extermination and the State', Theory, Culture \& Society, 18 (2-3): 265-76.

Weber, Alfred (1935) Kulturgeschichte als Kultursoziologie. Munich: Piper. 
Weber, Alfred (1998 [1921]) 'Fundamentals of culture-sociology: social process, civilizational process and culture-movement', in John Rundell and Stephen Mennell (eds), Classical Readings in Culture and Civilization. London: Routledge, pp. 191-215.

Wilterdink, Nico (1973) 'Norbert Elias en onze beschaving', in NRC Handelsblad 26 mei 1973: Z8.

Wilterdink, Nico (1977) 'Norbert Elias's sociology of knowledge and its significance for the study of the sciences', in Human Figurations: Essays for/Aufsätze für Norbert Elias. Amsterdam, Stichting Amsterdams Sociologisch Tijdschrift, pp. 110-26.

Wilterdink, Nico (1995) 'Civilisatie en cultuur opnieuw bezien', Amsterdams Sociologisch Tijdschrift 22 (2): 350-67.

Wilterdink, Nico (1997) 'Naschrift' Amsterdams Sociologisch Tijdschrift 24 (1): $130-1$.

Wouters, Cas (1976) 'Is het civilisatieproces van richting veranderd?', Amsterdams Sociologisch Tijdschrift 3 (3): 336-60.

Wouters, Cas (1986) 'Formalisation and Informalisation: Changing Tension Balances in Civilising Processes.' Theory, Culture \& Society 3: 1-19.

Wouters, Cas (1997) 'Criteriologie: weer op zoek naar richtingaanwijzers in civilisatieprocessen’, Amsterdams Sociologisch Tijdschrift 24 (1): 124-9.

Wouters, Cas (2004) Sex and Manners. Female Emancipation in the West 1890 2000. London, Sage.

Wouters, Cas (2007) Informalization: Manners and Emotions since 1890. London: Sage.

Wouters, Cas (2010) Review of Civility: A Cultural History by Benet Davetian,, in Figurations 33: 10-11.

Wouters, Cas (2011a) 'Have sexualization processes changed direction?', Sexualities 14 (1): 1-19.

Wouters, Cas (2011b) 'Status Competition and the Development of an American Habitus', in Christa Buschendorf, Astrid Franke, and Johannes Voelz (eds), Civilizing and Decivilizing Processes: Figurational Approaches to American Culture. Newcastle upon Tyne: Cambridge Scholars Publishing, pp. 263-86.

« listing» p.106-107. 